1 This article was published in Journal of Environmental Chemical Engineering, 2, 1027-1039, 22014

3 http://dx.doi.org/10.1016/j.jece.2014.03.019

\title{
Synthetic Textile Dyeing Wastewater Treatment by Integration of Advanced Oxidation and Biological Processes - Performance Analysis with Costs Reduction
}

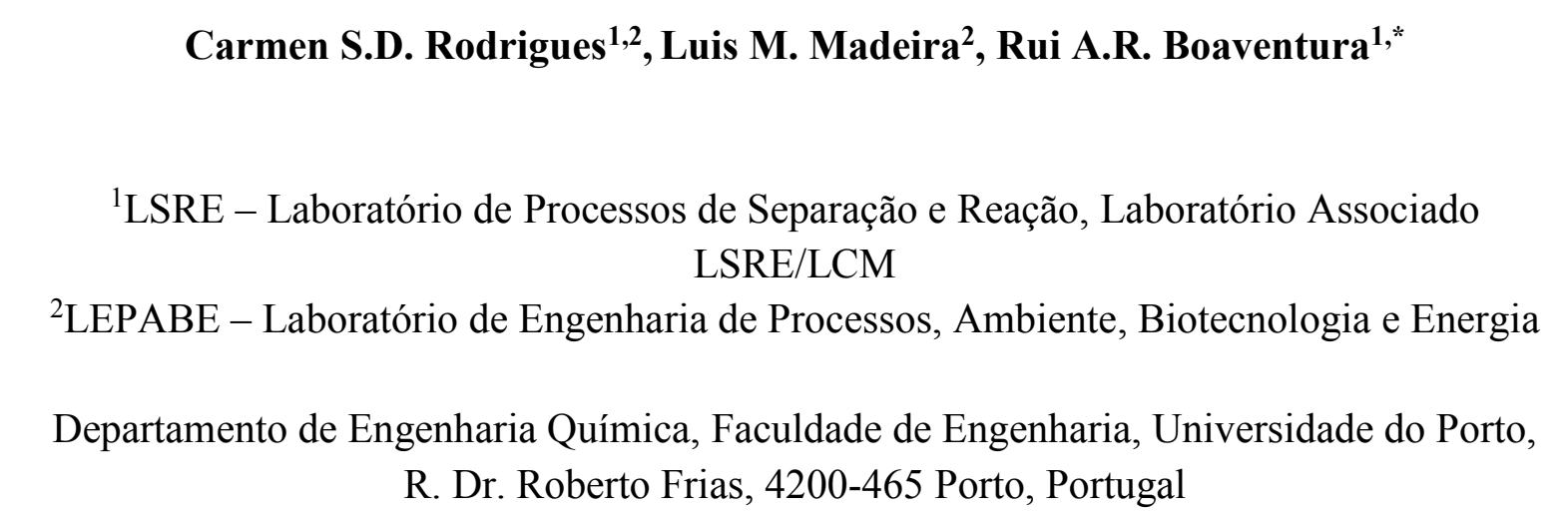

(1)

26

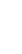

(2)


Abstract

41 Color and organic matter removals from acrylic, cotton and polyester dyeing wastewaters were

42 evaluated by biological oxidation in a Sequential Batch Reactor (SBR) and by integration of Fenton's

43 reaction with SBR. Raw and chemically oxidized pre-treated wastewaters were fed to the biological

44 reactor during 10 cycles (i.e., up to pseudo-steady state conditions). Because the biological degradation

45 did not allow obtaining effluents complying with the discharge limits, neither did the chemical

46 oxidation per se, coupling the SBR after chemical oxidation was required. In the integrated chemical-

47 biological process a new strategy was applied in the optimization of Fenton's oxidation, consisting in

48 the application of the optimum doses of $\mathrm{Fe}(\mathrm{II})$ and $\mathrm{H}_{2} \mathrm{O}_{2}$ (for biodegradability enhancement and

49 maximization of color and DOC removals), but with the simultaneous objective of minimizing the

50 operating costs. The integration of Fenton's oxidation with a downstream SBR provides much better

51 removals of organic matter $\left(88-98 \%\right.$ for $\mathrm{COD}, 83-95 \%$ for $\mathrm{BOD}_{5}$ and $91-98 \%$ for DOC, values

52 depending on the particular textile effluent being used) and color ( $>99 \%)$ than the biological or

53 chemical treatment alone. Besides, such integrated treatment allows treated wastewaters to meet the

54 discharge limits with a reduction of the operating costs, in the range $24-39 \%$ comparatively to Fenton's

55 oxidation alone.

69 Keywords: Textile dyeing wastewaters; Fenton's oxidation; SBR; Economic analysis. 


\section{Introduction}

75 Negative environmental impacts are often associated with the textile dyeing industry, mainly due to the discharge of wastewaters, which impair the aquatic environment quality by changing its color and creating conditions for eutrophication, low reoxigenation and a decrease in the solar light penetration [1]. Considering the growing awareness and concern about the negative effects on the environment generated by the discharge of industrial wastewaters, increasingly restrictive legislation regarding the concentrations of pollutants in the effluents has been approved. Therefore, it is necessary to develop and implement treatment technologies more efficient and also economically viable or at least attractive. In the present study, the treatability of acrylic, cotton and polyester dyeing wastewaters by a biological aerobic process (SBR - sequential batch reactor) and a combined process (Fenton's oxidation followed by SBR) was evaluated. While in principle the biological process is economically far more attractive, when used alone it might not be efficient enough; so, integration with other processes has been envisaged by several authors [2].

87 The Fenton's reaction is based on the decomposition of hydrogen peroxide catalyzed by ferrous iron

88 (eq. 1), in acid medium, generating highly reactive species like HO• radicals, without requiring high 89 pressure and temperature; such features make the process easily applicable and attractive [3]. The 90 hydroxyl radical oxidizes the dyes and other organics (cf. eq. 3) present in the wastewaters in 91 accordance with the following simplified reaction scheme [4]:

$$
\mathrm{k}_{1}=76 \mathrm{~L} /(\text { mol.s })
$$

$94 \mathrm{Fe}^{3+}+\mathrm{H}_{2} \mathrm{O}_{2} \rightarrow \mathrm{Fe}^{2+}+\mathrm{HO}_{2}^{\bullet}+\mathrm{H}^{+}$

$\mathrm{k}_{2}=0.01-0.02 \mathrm{~L} /(\mathrm{mol} . \mathrm{s})$

$95 \mathrm{HO}^{\bullet}+\mathrm{RH} \rightarrow \mathrm{H}_{2} \mathrm{O}+$ intermediates

Then, the intermediates may suffer further oxidation by the HO• species, hopefully till carbon dioxide, which would represent complete mineralization. In this simplified mechanism, eq. 2 refers to catalyst regeneration in the redox process. The textile effluent to treat is very often first subjected to Fenton's oxidation to degrade part of the organic matter, while removing completely the color and increasing the biodegradability and/or

103 batch reactor aerobic bacteria are used, as in the conventional activated sludge systems, to degrade the 104 biodegradable fraction of the organic matter into new compounds, cells, salts and gases. The SBR 105 operates in discontinuous mode with five sequential stages in each treatment cycle (influent feeding, 106 reaction, sedimentation, discharge of the clarified effluent and sludge purge and idle). This process 
present some advantages compared to other conventional biological treatments, namely simplicity and

108 flexibility, low cost, and increased resistance to fluctuations in the influent [5]. Additionally,

109 equalization, reaction and clarification occur in the same reactor [6].

110 SBRs have been successfully employed for the removal of nutrients present in domestic wastewaters

111 [7] and pollutants from industrial effluents, namely dairy [8], paper mill [9], piggery [10], textile 112 wastewaters [11-17] and landfill leachate [18-19]. The combination of chemical oxidation like Fenton's 113 reagent and SBR has also been reported in the literature as regards the removal of dyes in aqueous 114 solution [20-21] and the improvement of textile effluents treatment [22-24]. In the literature, there are 115 studies that compare electrocoagulation, coagulation and Fenton [25] and combination the oxidation 116 with biological degradation in aerobic, anoxic and anaerobic [26].

117 In this work, a treatability study of synthetic acrylic, cotton and polyester dyeing wastewaters 118 (representing typical dyeing industrial effluents) was done, either using an SBR or an integrated 119 process combining the Fenton's reaction with an SBR process. The main purpose of this research was 120 to evaluate the possibility of reducing the chemicals consumption in the Fenton's reaction to make the 121 pre-treated effluents able to be fed to a subsequent biological treatment, while obtaining final effluents 122 that accomplish the maximum allowable limits imposed by legislation for discharge into the aquatic 123 environment, at a lower operating cost. So, an economic analysis was also performed, since it is very 124 important to maximize wastewater treatment efficiency while reducing running costs. Up to the author's 125 knowledge, none scientific report in this area has addressed a similar approach, i.e., maximizing treatment efficiency while simultaneously minimizing operating costs.

\section{2. Materials and Methods}

\subsection{Synthetic Wastewaters Preparation}

132 In this work a real wastewater was not used because its characteristics change dramatically from day to 133 day, which is inherent to the operation mode of textile dye-houses. So, synthetic effluents with 134 composition similar to real wastewaters were prepared in accordance with the information presented in 135 Table 1. Basically, it was taken into account the amount of dyes (Procion Deep Red H-EXL gran, 136 Procion Yellow H-EXL gran, Astrazon Blue FGGL 300\%, Dianix Orange K3G and Dianix Blue 137 KFBL) and auxiliaries used in the dyeing baths, and the percentage of these products unfixed by the 138 fibers (rejection percentage). Such information was supplied by the dye-house Erfoc - Acabamentos 139 Têxteis S.A. (Famalicão, Portugal) - and by DyStar Anilinas Têxteis, Unip Ltd (Portugal), allowing 140 thus estimating the concentration of each species in the polyester, acrylic or cotton synthetic effluents. 


\subsection{Experimental Procedure}

144 Fenton's oxidation was carried out as follows: a given volume of synthetic dyeing wastewater was put 145 into a batch jacketed reactor. After temperature stabilization (at $50^{\circ} \mathrm{C}$ ), the $\mathrm{pH}$ was adjusted to 3.5 with $1460.5 \mathrm{M} \mathrm{H}_{2} \mathrm{SO}_{4}$ (from Merck). The catalyst $\left(\mathrm{FeSO}_{4} \cdot 7 \mathrm{H}_{2} \mathrm{O}\right.$, from Merck) was then added and the reaction 147 started with the addition of $\mathrm{H}_{2} \mathrm{O}_{2} 30 \%$ (w/v) (Merck). During the reaction the solution was constantly 148 stirred by using a mechanic stirrer (VWR VOS power control, from Germany). After 60 minutes of reaction, the residual hydrogen peroxide was eliminated by raising the $\mathrm{pH}$ to 12.3 through the addition of $10 \mathrm{M} \mathrm{NaOH}$ (from Merck) and heating the samples at $80{ }^{\circ} \mathrm{C}$ for 10 minutes [27, 28]. Under alkaline conditions, the iron precipitated and was then removed by sedimentation. The supernatant was neutralized (to $\mathrm{pH} \sim 7.0$ ) with concentrated $\mathrm{H}_{2} \mathrm{SO}_{4}$ (from Merck) and then analyzed and/or fed to the SBR (Sequential Batch Reactor).

154 The $\mathrm{pH}$, temperature and reaction time were fixed at the values that maximize color and DOC removals and improve the biodegradability of the raw wastewaters, which were reached in previous studies where Fenton's oxidation alone was applied to the same effluents [29-31].

157 The SBR is a jacketed cylinder $\left(20 \mathrm{~cm}\right.$ internal diameter, $45 \mathrm{~cm}$ total height and $30^{\circ}$ slope conical 158 bottom; effective working volume $=5.0 \mathrm{~L}$ ) connected to a thermostatic bath (Isco GTR 90, from Italy).

159 Figure 1 illustrates the installation set-up. The biological reactor was operated at constant temperature $160\left(25^{\circ} \mathrm{C}\right)$ during 12 hours per cycle $(1 \mathrm{~h}$ for feeding, $6 \mathrm{~h}$ of reaction, $4 \mathrm{~h}$ of sedimentation, $0.8 \mathrm{~h}$ for 161 discharge and $0.2 \mathrm{~h}$ idle), up to 10 cycles. In the first cycle the reactor was fed with $2.5 \mathrm{~L}$ of wastewater 162 with $\mathrm{pH}$ previously adjusted to 7.0 using $1 \mathrm{M} \mathrm{H}_{2} \mathrm{SO}_{4}$ and $10 \mathrm{M} \mathrm{NaOH}$, after adding phosphorus (as 163 phosphate buffer) or nitrogen (as urea) whenever necessary to ensure the minimum quantity required 164 for biological treatment $\left(\mathrm{BOD}_{5}: \mathrm{N}: \mathrm{P}\right.$ ratio of 100:5:1). Then $2.5 \mathrm{~L}$ of activated sludge $(\sim 5 \mathrm{~g}$ VSS/L) 165 from the aeration tank of the Rabada WWTP (Santo Tirso - Portugal) were added to the reactor, 166 resulting in a final volume of $5.0 \mathrm{~L}$. In subsequent cycles the reactor was fed with $2.5 \mathrm{~L}$ of effluent to 167 compensate the amount of treated effluent discharged. During the reaction stage, a mechanical stirrer 168 was employed (stirring rate $=400 \mathrm{rpm}$ ) and the dissolved oxygen content was maintained at $3.0 \pm 1.3$ $169 \mathrm{mg} \mathrm{O}_{2} / \mathrm{L}$ by aeration using air diffusers. The values of temperature, dissolved oxygen and duration of 170 each cycle and each cycle stage were established in accordance with literature [6,14,23,32-36].

171 The $\mathrm{pH}$ (electrode HI 1332 and pH-meter HI 8720E from Hanna Instruments, Italy), temperature 172 (thermocouple type K) and ORP - Oxidation-Reduction Potential (electrode HI 3230 and mV-meter HI 173 8711E from Hanna Instruments, Italy) were continuously monitored (cf. Fig. 1). At the end of each 174 cycle, total suspended solids (TSS), biological oxygen demand $\left(\mathrm{BOD}_{5}\right)$, chemical oxygen demand 
175 (COD), dissolved organic carbon (DOC), absorbance at a predefined wavelength (which depends on 176 the effluent to be treated), total nitrogen and total phosphorus were determined in the effluent 177 discharged, as detailed in the following section. The content of volatile suspended solids (VSS) was

178 measured, in some cycles, in samples collected inside the reactor.

179 The data acquisition and the automatic control of the unit, i.e., operation of the peristaltic pumps 180 (Watson-Marlow 502S, England), Burckert valve (from Germany) and mechanical stirrer (VWR VOS 181 power control, Germany), were achieved by using the software Labview 5.0 (National Instruments), 182 through a home-designed interface.

\subsection{Analytical Methods}

The color of the samples was quantified by measuring the absorbance at the wavelength corresponding to the maximum absorbance of each effluent $(610 \mathrm{~nm}$ and $520 \mathrm{~nm}$ for acrylic and cotton dyeing wastewater, respectively; polyester effluents are colorless), using a molecular absorption spectrophotometer (Pye Unicam, model Helios $\alpha$, Germany). As the absorbance of the synthetic wastewater varies with $\mathrm{pH}$, this was previously adjusted to the value of the treated effluent. The biodegradability was evaluated by measuring the specific oxygen uptake rate (SOUR) at $20{ }^{\circ} \mathrm{C}$.

192 The samples were inoculated with biomass from the activated sludge tank of a WWTP treating textile 193 effluent, and the dissolved oxygen concentration measured for 30 min (using a YSI Model $5300 \mathrm{~B}$ 194 biological oxygen monitor, from USA). SOUR $\left(\mathrm{mgO}_{2} / \mathrm{g}_{\mathrm{vss}} \cdot \mathrm{h}\right)$ was calculated as the ratio between the oxygen concentration decay rate (which was linear during the above-mentioned period) and the volatile suspended solids (VSS) concentration after the addition of the inoculum (700 $\mathrm{mg}$ VSS/L) [36-37]. The inhibition of Vibrio fischeri test was performed according to the standard DIN/EN/ISO 11348-3 [38]. The bacteria were put in contact with samples at $15^{\circ} \mathrm{C}$ and the bioluminescence measured after a contact time of 5, 15 or 30 minutes in a Microtox model 500 analyzer (England).

Other analytical determinations were carried out according to Standard Methods [37]: dissolved organic carbon (DOC) was measured in a TC/TOC analyzer (Shimadzu 5000A, from Japan) - Method 5310 D; the biochemical oxygen demand $\left(\mathrm{BOD}_{5}\right)$ was determined according to Method $5210 \mathrm{~B}$; the chemical oxygen demand (COD) was assessed by the open reflux method (Method 5220 B) for acrylic and polyester effluents, as higher dilutions are required due to the high chloride concentration, and by the closed reflux method (Method 5220 D) for the cotton wastewater; and total phosphorus by Method 4500P - E. Total nitrogen was determined by colorimetry according to Method D992-71 from ASTM Standards [39] after previous digestion (Method 4500 - N C). Total suspended solids (TSS) and volatile suspended solids (VSS) were quantified by gravimetry - Method 2540 B and Method 2540 E, 
respectively. Finally the alkalinity was evaluated by titration with $\mathrm{H}_{2} \mathrm{SO}_{4}$ at $\mathrm{pH} 4.5$ (Method $2320 \mathrm{D}$ )

210 while the $\mathrm{pH}$ was measured using a selective electrode (Hanna Instruments HI 1230) and a pH-meter

211 (Hanna Instruments $\mathrm{HI}$ 8424, Italy); the conductivity at $20^{\circ} \mathrm{C}$ was determined using a conductivity 212 probe (WTW TetraCon 325, Germany) and a conductivity meter (WTW LF538, Germany) - Method $2132510 \mathrm{~B}$.

214 All analytical determinations were performed in duplicate and the coefficients of variation were less

215 than to $2 \%$ for DOC, $8 \%$ for $\mathrm{BOD}_{5}, 4 \%$ for COD and SOUR, $3 \%$ for inhibition of $V$. fisheri and $5 \%$ for

216 the other parameters.

\section{Results and Discussion}

The more relevant characteristics of the synthetic acrylic, cotton and polyester dyeing wastewaters used in this study are reported in Table 2. Cotton and acrylic wastewaters are colored even at 1:40 dilution but polyester effluent is practically colorless. The organic load (expressed as COD or DOC) is moderate for all wastewaters but the biodegradability is low as indicated by the $\mathrm{BOD}_{5}$ : $\mathrm{COD}$ ratio and the values of SOUR; actually, the acrylic wastewater can be classified as non biodegradable and the other wastewaters can be considered as only slightly biodegradable. Acrylic and polyester effluents strongly inhibit $V$. fisheri activity, which proves their toxicity. Taking into account the low biodegradability and the high toxicity (except for the cotton wastewater), a biological treatment of these wastewaters does not probably allow meeting the discharge limits, as established by the Portuguese legislation (cf. Table 2). Even so, the feasibility of using a biological process (SBR) alone or downstream from a chemical oxidation process (Fenton's reaction) to achieve the discharge limits was investigated in this study. The results obtained when applying this strategy for treating the three different kinds of textile dyeing wastewaters are shown in the next sections.

\subsection{Biological Treatment}

The biological degradation was only applied to raw polyester and cotton effluents because the acrylic one presents very low biodegradability $\left(\mathrm{BOD}_{5} / \mathrm{COD}\right.$ ratio $<0.0012$ and SOUR $<0.2 \mathrm{mg} \mathrm{O} / \mathrm{g}_{\mathrm{vss}} . \mathrm{h}$ (Table 2), also confirmed by the Zhan Wells test (data not shown), which indicated that the degradation obtained after 28 days does not exceed $15 \%$.

240 Figure 2 shows the $\mathrm{COD}, \mathrm{BOD}_{5}, \mathrm{DOC}$, total nitrogen and color removals obtained in 10 successive 241 cycles of SBR treatment of polyester and cotton effluents; no further cycles were applied because nearly 242 steady-state conditions were reached in all cases, i.e., stable performances in consecutive cycles. The 
243 polyester effluent exhibits a considerable increase of $\mathrm{COD}, \mathrm{BOD}_{5}, \mathrm{DOC}$ and total nitrogen removal 244 during the first 5 cycles that continue to increase, albeit more slowly, up to the 7 th cycle, and then 245 remain almost constant with average values of $24,39,40$ and $16 \%$ for $\mathrm{COD}, \mathrm{BOD}_{5}, \mathrm{DOC}$ and nitrogen, 246 respectively. For the cotton effluent the removals also increase during the first 5 cycles and then the 247 removal rate decreases or maintains constant leading to average final values of $20 \%$ for $\mathrm{COD}, \mathrm{BOD}_{5}$, 248 and COD and $21 \%$ for nitrogen. The low efficiencies achieved can be explained by the presence in the 249 effluents of a significant proportion of refractory or only slightly biodegradable compounds, as could 250 be inferred from the low $\mathrm{BOD}_{5} / \mathrm{COD}$ ratios and SOUR values, particularly for the cotton one (cf. Table 251 2). As regards color removal, in the cotton wastewater the values of absorbance at $520 \mathrm{~nm}$ decreased 252 in the first 4 cycles and kept constant in the subsequently cycles, achieving an average value of $51 \%$ of 253 decolorization. The removal may be the result of some biological degradation of the textile dyes present 254 in the effluent but the adsorption onto the biomass flocs probably also contributes for color elimination 255 [40]. The color removal obtained for cotton wastewater is similar to that reported by Vaigan et al. [41]. 256 These authors achieved color removals of $31-57 \%$ when treating 20 to $40 \mathrm{mg} / \mathrm{L}$ of reactive Blue B-16, 257 respectively, in an SBR.

258 With regard to other monitored parameters, whose values are not presented in Fig. 2, it was noted that 259 during all SBR cycles the concentrations in the treated effluents were in the range $2.4-2.9 \mathrm{mg} \mathrm{P} / \mathrm{L}, 22$ $260-29 \mathrm{mg} \mathrm{TSS} / \mathrm{L}$ and 2530-2970 $\mathrm{mg} \mathrm{VSS} / \mathrm{L}$ for the polyester effluent and $5.7-5.9 \mathrm{mg} \mathrm{P} / \mathrm{L}, 27-32 \mathrm{mg}$ $261 \mathrm{TSS} / \mathrm{L}$ and 2350-2680 mg VSS/L for the cotton one.

262 The pseudo-steady state was reached after ca. 7 cycles for both cotton and polyester effluents. Table 2 263 presents the average values of different parameters after reaching the pseudo-steady state. It can be 264 concluded that the effluents resulting from biological treatment do not meet the discharge limits, since 265 the valuesof COD (392.4 and $280.4 \mathrm{mg} / \mathrm{L}$ for polyester and cotton, respectively) are above $250 \mathrm{mg} / \mathrm{L}$ 266 and the color of the cotton effluent is visible after 1:40 dilution. So, a pre-treatment or subsequent 267 treatment is required. We choose to apply the chemical oxidation by Fenton's reagent as pre-treatment 268 to enhance the biodegradability and remove color and, then, subject the wastewater to biological 269 treatment. The results obtained from the combined process are presented in the following section.

\subsection{Integration of Fenton's Reagent followed by Biological Treatment}

274 As the oxidation process allows increasing the biodegradability of the acrylic and cotton effluents while 275 reducing the toxicity of the acrylic and polyester effluents, as shown below (cf. Tables 3-5), the 276 combination of Fenton reaction with the biological oxidation in SBR was studied. Aiming reducing the 277 doses of chemicals, and inherently the operating costs (described in the following section), three 
experiments were performed, i.e., the preliminary Fenton reaction stage was performed with different doses of reagents. The $1^{\text {st }}$ run was performed at the best conditions for maximizing color and DOC removals and improving biodegradability already determined in previous studies [29-31], for effluents that have exactly the same composition as those used in this work: $\left[\mathrm{H}_{2} \mathrm{O}_{2}\right]=20 \mathrm{~g} / \mathrm{L}$ and $\left[\mathrm{Fe}^{2+}\right]=350 \mathrm{mg} / \mathrm{L}$ for acrylic, $\left[\mathrm{H}_{2} \mathrm{O}_{2}\right]=10 \mathrm{~g} / \mathrm{L}$ and $\left[\mathrm{Fe}^{2+}\right]=300 \mathrm{mg} / \mathrm{L}$ for cotton and $\left[\mathrm{H}_{2} \mathrm{O}_{2}\right]=2.5 \mathrm{~g} / \mathrm{L}$ and $\left[\mathrm{Fe}^{2+}\right]=350 \mathrm{mg} / \mathrm{L}$ for polyester wastewaters, all at $\mathrm{pH} 3.5$ and $50^{\circ} \mathrm{C}$. In runs \#2 and \#3 the doses of hydrogen peroxide and ferrous iron were reduced to $3 / 4$ and $1 / 2$ for acrylic and $1 / 2$ and $1 / 4$ for polyester and cotton effluents, respectively, with the aim of decreasing the treatment cost (associated with the consumption of chemicals in the Fenton's process) while obtaining a final effluent that should meet the discharge limits imposed by the national legislation for the textile industry.

288 Results obtained during the Fenton's oxidation stage have been reported previously (in the works mentioned above) and only overall performances reached are described herein - run \#1 in Tables 3, 4 and 5 for the acrylic, cotton and polyester effluents, respectively. It is noteworthy that the selected $\mathrm{H}_{2} \mathrm{O}_{2}$ concentrations are high, particularly for the acrylic and cotton wastewaters $(20$ and $10 \mathrm{~g} / \mathrm{L}$, respectively). The effluents under study are medium-strength ones (in terms of organic matter) but rather complex as concerns the inorganic content. So, unwanted parallel reactions (e.g. HO• scavenging by chlorides, sulfates and carbonates, etc.) take place and therefore an excess of oxidant is required [2931].

Regarding the results obtained in the SBR, Figure 3 shows the removal performances obtained, in terms of $\mathrm{COD}, \mathrm{BOD}_{5}, \mathrm{DOC}$, total nitrogen and color for the acrylic wastewater. It can be observed that removals increased during the first 4 cycles, although the improvement is more notorious in the $1^{\text {st }}$ and $2^{\text {nd }}$ runs; therefore, we can say that the pseudo-steady state was reached at end of 4-5 cycles. After reaching the pseudo-steady sate, the average removals achieved in the SBR for the parameters analyzed are higher in run $\# 1\left(95,95,95,45\right.$ and $68 \%$ for $\mathrm{COD}_{1} \mathrm{BOD}_{5}, \mathrm{DOC}$, total nitrogen and color, respectively), followed by run $\# 2\left(65,85,72,42\right.$ and $69 \%$ for $\mathrm{COD}, \mathrm{BOD}_{5}, \mathrm{DOC}$, total nitrogen and color, respectively) and then by run $\# 3\left(22,69,17,23\right.$ and $72 \%$ for COD, $\mathrm{BOD}_{5}, \mathrm{DOC}$, total nitrogen and color, respectively). The reason is that from run \#1 to run \#3 less chemicals were used in the Fenton's stage, so that the effluent fed to the SBR is less biodegradable (cf. Table 3). In runs \#1 and \#2 it was possible to reach, after the integrated treatment, an effluent that is ready for discharge into water bodies - see Table 3. On the other hand, although in run \#3 less chemicals were employed in the

308 Fenton's stage as compared to run \#2, it was not possible to fulfill the limits imposed by the national 309 legislation for the discharge of textile effluents, namely in terms of COD (cf. Table 3).

310 The removals obtained during 10 cycles of SBR for the cotton effluent previously treated by Fenton's 311 oxidation are shown in Figure 4. During the first 6 cycles an increase was observed for all runs, and 
312 then the removals remain nearly constant, which means that the pseudo-steady state was reached. In

313 runs $\# 1$ and $\# 2$ the average values of $\mathrm{COD}, \mathrm{BOD}_{5}$ and visible color (after dilution of 1:40) at the outlet

314 of the SBR, during the last 4 cycles of operation, are smaller than the maximum allowable discharge

315 values (see Table 4). This is however not the case of run \#3, in which very low doses of chemicals were

316 used in the Fenton's oxidation (25\% of those employed in run \#1); thus, final effluent shows COD

317 values not complying with the legislated standard.

318 As far as concerns the polyester dyeing wastewater biological treatment, 6-7 cycles are needed for

319 reaching the pseudo-steady state (cf. Figure 5), after the Fenton's oxidation. The average removal

320 values achieved after 7 cycles are higher in the $1^{\text {st }}$ run $(80,82,80$ and $19 \%$ for COD, BOD, DOC and

321 total nitrogen, respectively), followed by the $2^{\text {nd }}$ one $(64,63,66$ and $19 \%$ for COD, BOD 5, DOC and

322 total nitrogen, respectively) and then by $3^{\text {rd }}$ one $\left(31,48,46\right.$ and $16 \%$ for $\mathrm{COD}, \mathrm{BOD}_{5}$, $\mathrm{DOC}_{\text {and }}$ total

323 nitrogen, respectively); this is the order of decreased doses of chemicals in the previous chemical

324 oxidation process. Again, the wastewater resulting from the SBR operating in the conditions used in

325 runs \#1 and \#2 can be discharged into water bodies, because the values of the legislated parameters are

326 smaller than the discharge limits for the textile industry (see Table 5).

327 The high overall COD and color removal efficiencies obtained in run\#1, for the three effluents, are very

328 similar to those reported by Tantak and Chaudhari [20] (>95\% for color vs. $>98 \%$ in our work, and in

329 the range $78-86 \%$ for COD vs. $88-98 \%$ in our work); such authors treated, by Fenton's oxidation and

330 SBR, aqueous solutions of textile dyes (Reactive Black 5, Reactive Blue 13 and Acid Orange 7).

\subsection{Costs Evaluation}

333 The overall costs of the treatment process are represented by the sum of the capital, operating and 334 maintenance costs. For a full-scale system these costs depend on the flow rate of the effluent, the nature 335 of the wastewater, as well as on the configuration of the reactor(s). Moreover, the neutralization of pre336 treated effluent by the Fenton process generates chemical sludge. The costs associated with the 337 deposition of the sludge were not accounted for because they can vary considerably, depending on the 338 treatment processes adopted (thickening / conditioning / drying) and on the price to landfill the 339 industrial waste. So, in this study, we considered only the costs with chemicals: ferrous sulfate and 340 hydrogen peroxide, as well as the acid and base required for acidification $\left(0.01,0.11\right.$ and $0.63 € / \mathrm{m}^{3}$ for 341 acrylic, polyester and cotton effluents, respectively) and subsequent neutralization $\left(0.01 € / \mathrm{m}^{3}\right.$ for 342 acrylic, $0.19 € / \mathrm{m}^{3}$ for polyester and $1.09 € / \mathrm{m}^{3}$ for cotton effluents, respectively), and energy consumed 343 in agitation (power required $=0.61 \mathrm{~W}$ ) and air insufflation (power required $=4.5 \mathrm{~W}$ ) in the SBR stage. 
344 The costs of reagents used in the Fenton's stage were obtained from Quimitécnica S.A. (Portugal) and 345 the average values considered were as follows: $\mathrm{H}_{2} \mathrm{O}_{2}\left(49.5 \% \mathrm{w} / \mathrm{v}\right.$, density at $\left.25^{\circ} \mathrm{C}=1.2 \mathrm{~g} / \mathrm{cm}^{3}\right)-365$ $346 € /$ ton; $\mathrm{FeSO}_{4} .7 \mathrm{H}_{2} \mathrm{O}(93 \%$ of purity $)-233.7 € /$ ton; $\mathrm{H}_{2} \mathrm{SO}_{4}\left(96 \% \mathrm{w} / \mathrm{v}\right.$, density $\left.=1.84 \mathrm{~kg} / \mathrm{dm}^{3}\right)-140 € /$ ton; $347 \mathrm{NaOH}\left(30 \% \mathrm{w} / \mathrm{w}\right.$, density $\left.=1.33 \mathrm{~kg} / \mathrm{dm}^{3}\right)-185 € /$ ton. For energy it was considered the average value 348 of $0.10 € / \mathrm{kWh}$.

349 Figure 6 shows the total operating cost of the Fenton's oxidation alone, biological treatment and the 350 combination of both techniques, considering the conditions of runs \#1, \#2 and \#3 mentioned above. 351 The inclusion of a pre-treatment (Fenton's reaction) led to a significant increase in the operating costs 352 (overall cost for the different runs amounting to values in the range $2.2-4.2$ and $5.2-12.1 € / \mathrm{m}^{3}$ in the 353 combination Fenton+SBR for polyester and cotton, respectively, compared with $1.2 € / \mathrm{m}^{3}$ in SBR 354 alone). However, the biological treatment directly applied to the effluents does not allow meeting the 355 discharge limits. As could be expected, in the integrated process (chemical and biological oxidation), 356 the costs raised when increasing the doses of the reagents used in the Fenton stage (higher in run \#1, 357 for all effluents).

358 Since the objective of this study was to obtain an effluent complying with the discharge limits after 359 treatment (runs \#1 and \#2 for the acrylic, cotton and polyester effluents) at the lowest treatment cost, 360 the selected operating conditions were those of run\# 2 for acrylic (total cost of $\left.14.8 € / \mathrm{m}^{3}\right)$, cotton $(7.5$ $\left.361 € / \mathrm{m}^{3}\right)$ and polyester $\left(2.9 € / \mathrm{m}^{3}\right)$ wastewaters, using an integrated process of Fenton' oxidation and SBR.

362 The operating costs are associated with the consumption of hydrogen peroxide and iron in the oxidative 363 process, which follows the order: acrylic $>$ cotton $>$ polyester. The hydrogen peroxide consumption is 364 associated with the larger amount of organic matter (acrylic has higher values of COD and DOC), but 365 also with the high content of chlorides ( $\sim \mathrm{g} / \mathrm{L}$ in the cotton effluent).

366 The total costs of the integrated process (run\# 2) are smaller than those corresponding to the Fenton's 367 reaction alone $\left(18.1,10.9\right.$ and $2.7 € / \mathrm{m}^{3}$ for acrylic, cotton and polyester effluents, respectively), which, 368 even so, did not allowed per se obtaining effluents respecting legislated standards.

\section{Conclusions}

372 The treatability of synthetic acrylic, cotton and polyester dyeing wastewaters by SBR and an integrated 373 process consisting of Fenton's reaction and SBR was investigated. It was found that the biological 374 degradation in SBR per se did not allow obtaining effluents complying with the discharge limits, the 375 same applying for the chemical oxidation stage when used alone. Fenton's oxidation improved the 
376 biodegradability of all dyeing wastewaters while reducing their toxicity, which allows its integration

377 with a biological treatment. The application of Fenton's process in optimized conditions followed by

378 biological oxidation (SBR) provided effluents that comply with discharge limits, with global organic

379 matter removals of 98,88 and 91\% for COD, 95, 83 and 91\% for $\mathrm{BOD}_{5}$ and 98,92 and 91\% for DOC,

380 for acrylic, cotton and polyester wastewaters, respectively, and almost complete color reduction

381 (>99\%). Under such conditions total operating costs are significant: $19.4 € / \mathrm{m}^{3}$ for acrylic, $12.2 € / \mathrm{m}^{3}$ for

382 cotton and $4.2 € / \mathrm{m}^{3}$ for polyester. However, the operating costs might be decreased by reducing the

$383 \quad \mathrm{H}_{2} \mathrm{O}_{2}$ and $\mathrm{Fe}^{2+}$ doses without compromising compliance with discharge limits. The use of the lowest

384 doses of reagents that allowed meeting the discharge limits led to operating costs of 14.8, 7.5 and 2.9

$385 € / \mathrm{m}^{3}$ for acrylic, cotton and polyester effluents, respectively. These costs represent a reduction of 24-

$38639 \%$ as regards the application of Fenton's oxidation alone.

\section{Acknowledgments}

390 Carmen Rodrigues is grateful to FCT - Fundação para a Ciência e Tecnologia - for financial support 391 through the PhD grant (Ref. SFRH/BD/46704/2008).

392 The authors are thankful to ERFOC - Acabamentos Têxteis S.A. (Famalicão, Portugal) and DyStar 393 Anilinas Têxteis Unipessoal Lda., for kindly supplying the reagents for simulating the textile effluents, 394 to TRATAVE (WWTP of Rabada) for providing the aerobic sludge for the respirometric tests and 395 inoculation of the SBR, and to Quimitécnica for providing information about the chemical's prices. 


\section{References}

[1] B. Shi, G. Li, D. Wang, C. Feng, H. Tang, Removal of direct dyes by coagulation: The performance of preformed polymeric aluminum species, J. Hazard. Mat. 143 (2007) 567-574.

402 [2] A. Reife, H.S. Freeman, Environmental Chemistry of Dye and Pigments, John Wiley \& Sons, New 403 York, 1996.

404 [3] R.J. Bigda, Consider Fenton's Chemistry for Wastewater Treatment, Chem. Eng. Proc. 91 (1995) $405 \quad 62-66$.

406 [4] C. Walling, Fenton's reagent revisited, Accounts Chem. Res. 8 (1975)125-131.

407 [5] S. Suresh, R.K. Tripathi, M.N.G. Rana, Review on treatment of industrial wastewater using 408 sequential batch reactor, International Journal of Science Technology \& Management 2 (2011) 64-84. 409 [6] U.S. EPA, Wastewater, Techonology Fact Sheet: Sequencing Batch Reactors, U.S. Environmental 410 Prottection Agency, Office of Water, Washington, D.C., EPA 932-F-99-073, 1999.

411 [7] R.S. Bernardes, A. Klapwijik, Biological nutrient removal in a sequencing batch reactor treating 412 domestic wastewaters, Water Sci. Technol. 42 (1996) 321-328.

413 [8] B.A. Mohseni, H. Bazari, Biological treatment of dairy wastewater by sequencing batch reactor, 414 Iranian Journal of Environmental Health Science \& Engineering 1 (2004) 65-69.

415 [9] Y.F. Tsang, F.L. Hua, H. Chua, S.N. Sin, Y.J. Wang, Optimization of biological treatment of paper 416 mill effluent in a sequencing batch reactor, Bioresource Technol. 98 (2007) 2142-2147.

417 [10] J.-J. Su, C.-M. Kungd, J. Lina, W.-C. Liana, J.-F. Wu, Utilization of sequencing batch reactor for 418 in situ piggery wastewater treatment, J. Environ. Sci. Heal. A 32 (1997) 391-405.

419 [11] N.D. Lourenço, J.M. Novais, H.M. Pinheiro, Reactive textile dye colour removal in a sequencing 420 batch reactor, Water Sci. Techn. 42 (2000) 321-328.

421 [12] L.-y. Fu, X.-h. Wen, Q.-1. Lu, Y. Qian, Treatment of dyeing wastewater in two SBR systems, 422 Process Biochemistry 36 (2001) 1111-1118.

423 [13] L.N. Abu-Ghunmi, A.I. Jamrah, Biological treatment of textile wastewater using sequencing batch 424 reactor technology, Environ. Model. Assess. 11(2006) 333-343.

425 [14] S. Sirianuntapiboon, K. Chairattanawan, S. Jungphungsukpanich, Some properties of a sequencing 426 batch reactor system for removal of a vat dyes, Bioresource Technol. 97 (2006) 1243-1252. 
427 [15] S. Sirianuntapiboon, O. Sadahiro, P. Salee, Some properties of a granular activated carbon 428 sequencing batch reactor (GAC-SBR) system for treatment of textile wastewater containing direct dyes, 429 J. Environ. Manage. 85 (1) (2007) 162-170.

430 [16] I. Khouni, B. Marrot, R.B. Amar, Treatment of reconstituted textile wastewater containing a 431 reactive dye in an aerobic sequencing batch reactor using a novel bacterial consortium, Sep. Purif. 432 Technol. 87 (2011) 110-119.

433 [17] D.-Y. Ma, X.-H.. Wang, C. Song, M.-H. Fan, X.-M. Li, Aerobic granulation for methylene blue 434 biodegradation in a sequencing batch reactor, Desalination 276 (2011) 233-238.

435 [18] D. Kulikowsha, E. Klimiuk, Removal of organic and nitrogen from municipal landfill leachate in 436 two-stage SBR reactors, Pol. J. Environ. Stud. 13 (2004) 389-396.

437 [19] S. Morling, Nitrogen removal and heavy metals in leachate treatment using SBR technology, J. Hazard. Mater. 174 (2010) 679-686.

439 [20] N.P. Tantak, S. Chaudhari, Degradation of azo dyes by sequential Fenton's oxidation and aerobic 440 biological treatment, J. Hazard. Mater. B 136 (2006) 698-750.

441 [21] B. Lodha, S. Chaudhari, Optimization of Fenton-biological treatment scheme for the treatment of 442 aqueous dye solutions, J. Hazard. Mater. 148 (2007) 459-466.

443 [22] P. Fongsatitkul, P. Elefsiniotis, A. Yamasmit, N. Yamasmit, Use of sequencing batch reactors and 444 Fenton's reagent to treat a wastewater from textile industry, Biochem. Eng. J. 21 (2004) 213-220.

445 [23] C.S.D. Rodrigues, L.M. Madeira, R.A.R. Boaventura, Treatment of Textile Effluent by Chemical 446 (Fenton's Reagent) and Biological (Sequencing Batch Reactor) Oxidation, J. Hazard. Mater. 172 (2009) $447 \quad 1551-1559$.

448 [24] J. Blanco, F. Torrades, M. de la Varga, J. García-Montãno, Fenton and Biological-Fenton Coupled 449 Processes for Textile Wastewater Treatment and Reuse, Desalination 286 (2012) 34-399.

450 [25] I. Kabdaşli, I. Arslan-Alaton, B. Vardar, O. Tünay, Comparison of electrocoagulation, coagulation 451 and the fenton process for the treatment of reactive dyebath effluent, Water Sci Technol. 55 (2007) 452 125-134.

453 [26] I. Arslan-Alaton, B.H. Gursov, J.-E. Schmidt, Advanced oxidation of acid and reactive dyes: Effect 454 of Fenton treatment on aerobic, anoxic and anaerobic processes, Dyes Pigments 78 (2008) 117-130.

455 [27] J.B. Heredia, J.R. Domínguez, R. Lopez, Advanced Oxidation of Cork - Processing Wastewater 456 Using Fenton's Reagent: Kinetics and Stoichiometry, J. Chem. Technol. Biotechnol. 79 (2004) 407457412. 
[28] N.S.S. Martinez, J.F. Fernandez, X.F. Segura, A.S. Ferrer, Pre - Oxidation of an Extremely Polluted Industrial Wastewater by the Fenton's Reagent, J. Hazard. Mater. B 101 (2003) 315-322.

460 [29] C.S.D. Rodrigues, R.A.R. Boaventura, L.M.P. Madeira, Application of Fenton's Reagent for 461 Acrylic Dyeing Wastewater Decolorization, Organic Matter Reduction and Biodegradability 462 Improvement, J. Adv. Oxid. Technol. 15 (2012) 78-88.

463 [30] C.S.D. Rodrigues, R.A.R. Boaventura, L.M.P. Madeira, Combination of Coagulation/Flocculation 464 and Chemical Oxidation Processes for Treating a Cotton Dyeing Wastewater - Comparison of 465 Performances and Cost Analysis, International Journal of Environmental and Waste Management, in 466 press.

467 [31] C.S.D. Rodrigues, R.A.R. Boaventura, L.M.P. Madeira, Technical and Economic Feasibility of 468 Polyester Dyeing Wastewater Treatment by Coagulation/Flocculation and Fenton's Oxidation, 469 Environ. Technol. 35 (2014) 1307-1319.

470 [32] N.D. Lourenço, J.M. Novais, H.M. Pinheiro, Effect of some operational parameters on texile dye 471 biodegradation in sequential batch reactor, Biotechnology 89 (2001) 163-174.

472 [33] N. F. Gray, Biology of wastewater treatment, second edition, Imperial College Press, London, 4732004.

474 [34] J. García-Montaño, F. Torrades, J.A. García-Hortal, X. Domènech; J. Peral, Degradation of 475 Procion Red H-E7B reactive dye by coupling a photo-fenton system with sequencing batch reactor, J. 476 Hazard. Mater. B134 (2006) 220-229.

477 [35] Ö. Çinar, S. Yaşar, M. Kertmen, K. Demiröz, N.Ö. Yigit, M.M. Kitis, Effect of cycle time on 478 biodegradation of azo dye in sequencing batch reactor, Process Saf. Environ. 86 (2008) 455-460.

479 [36] R.S. Ramalho, Introduction to Wastewater Treatment Processes, Academic Press, New York, 480 USA, 1977.

481 [37] APHA, AWWA, WEF, Standard Methods for the Examination of Water and Wastewater, twenty482 third edition., American Public Health Association/American Water Works Association/Water 483 Environment Federation, Washington DC, USA, 1998.

484 [38] International Organization for Standardization, Water Quality - Determination of the Inhibitory 485 Effect of Water Samples on the Light Emission of Vibrio Fischeri (luminescent Bacteria Test) - Part 3: 486 Method Using Freeze-dried Bacteria, 2005.

487 [39] Annual Book of ASTM Standards, Water; Atmospheric Analysis, Part Twenty three, American 488 Society for Testing and Materials, Philadelphia, 1973. 
489 [40] B.D. Waters, The regulator's view. In Colour in Dyehouse effluent, P. Cooper (Ed.). Oxford, The 490 Society of Dyers and Coulorists, The Alden Press, 1995.

491 [41] A.A. Vaigan, R.A. Moghaddam, H. Hashemi, Effect of Dye concentration on sequencing batch 492 reactor performance, Iranian Journal of Environmental Health Science \& Engineering 6 (2009) 11-16. 
493 Table 1 - Chemicals present in each effluent, their doses used and rejections by the fibers, and estimated concentrations in the polyester, acrylic or cotton synthetic 494 effluents.

\begin{tabular}{|c|c|c|c|c|c|c|}
\hline Reagent & Function & Chemical Characteristic & Dyeing stage use & $\begin{array}{l}\text { Dyeing stage } \\
\text { Concentration }\end{array}$ & Rejection* & $\begin{array}{l}\text { Concentration } \\
\text { in the final } \\
\text { effluent }\end{array}$ \\
\hline \multicolumn{7}{|c|}{ Polyester effluent } \\
\hline Adranol NL & Anti-oil & - & Fiber preparation & $1 \mathrm{~g} / \mathrm{L}$ & $100 \%$ & $0.33 \mathrm{~g} / \mathrm{L}$ \\
\hline Antibacol R & Anti-crease & - & Fiber preparation & $1 \mathrm{~g} / \mathrm{L}$ & $100 \%$ & $0.33 \mathrm{~g} / \mathrm{L}$ \\
\hline Trissodic phosphate & Electrolyte & Salt & Fiber preparation & $1 \mathrm{~g} / \mathrm{L}$ & $90 \%$ & $0.30 \mathrm{~g} / \mathrm{L}$ \\
\hline Sera Gal PLP & Equalizing/dispersant & Alkyl polyglycol ether solution & Dyeing & $0.5 \mathrm{~g} / \mathrm{L}$ & $100 \%$ & $0.17 \mathrm{~g} / \mathrm{L}$ \\
\hline Antibacol R & Anti-crease & - & Dyeing & $1 \mathrm{~g} / \mathrm{L}$ & $100 \%$ & $0.33 \mathrm{~g} / \mathrm{L}$ \\
\hline Ammonium sulfate & Electrolyte & Salt & Dyeing & $2 \mathrm{~g} / \mathrm{L}$ & $90 \%$ & $0.60 \mathrm{~g} / \mathrm{L}$ \\
\hline Acetic acid & Acid generation & Acid & Dyeing & $0.5 \mathrm{~g} / \mathrm{L}$ & $100 \%$ & $0.17 \mathrm{~g} / \mathrm{L}$ \\
\hline Dianix Blue KFBL & Dyeing & Anthraquinone dye & Dyeing & $\begin{array}{c}0.71 \% \\
\text { (w dye/w fiber) }\end{array}$ & $5 \%$ & $0.012 \mathrm{~g} / \mathrm{L}$ \\
\hline Dianix Orange K3G & Dyeing & Azo dye & Dyeing & $\begin{array}{c}1.2 \% \\
\text { (w dye/w fiber) }\end{array}$ & $5 \%$ & $0.02 \mathrm{~g} / \mathrm{L}$ \\
\hline Sodium hydroxide $32 \%$ (w/v) & Alkaline system & Base & Washing & $3 \mathrm{~g} / \mathrm{L}$ & $100 \%$ & $1.0 \mathrm{~g} / \mathrm{L}$ \\
\hline Sodium hydrosulfite & Reducer system & Reducer & Washing & $3 \mathrm{~g} / \mathrm{L}$ & $90 \%$ & $0.90 \mathrm{~g} / \mathrm{L}$ \\
\hline \multicolumn{7}{|c|}{ Acrylic effluent } \\
\hline Sera con N-VS & Acid generator & Carboxylic acid ester solution & Dyeing & $0.4 \mathrm{ml} / \mathrm{L}$ & $100 \%$ & $0.13 \mathrm{ml} / \mathrm{L}$ \\
\hline Sera sperse M-IW & Dispersant & Alkyl polyglycol ether solution & Dyeing & $0.5 \mathrm{~g} / \mathrm{L}$ & $100 \%$ & $0.17 \mathrm{~g} / \mathrm{L}$ \\
\hline Sera tard A-AS & Retarder & N-alkyl-N, N-dimethylbenzylammonium & Dyeing & $1 \mathrm{~g} / \mathrm{L}$ & $100 \%$ & $0.33 \mathrm{~g} / \mathrm{L}$ \\
\hline Sodium sulfate & Electrolyte & Salt & Dyeing & $3 \mathrm{~g} / \mathrm{L}$ & $90 \%$ & $0.9 \mathrm{~g} / \mathrm{L}$ \\
\hline Sera lube M-CF & Anti-crease/lubricant & Polymeric amides solution & Dyeing & $2 \mathrm{~g} / \mathrm{L}$ & $100 \%$ & $0.67 \mathrm{~g} / \mathrm{L}$ \\
\hline Astrazon Blue FGGL 300\% 03 & Dyeing & Azo dye & Dyeing & $\begin{array}{c}1.5 \% \\
\text { (w dye/w fiber) }\end{array}$ & $5 \%$ & $0.008 \mathrm{~g} / \mathrm{L}$ \\
\hline \multicolumn{7}{|c|}{ Cotton effluent } \\
\hline Mouillant BG/JT & Anti-oil & Composition based in aliphatic ethoxylates & Fiber preparation & $0.7 \mathrm{ml} / \mathrm{L}$ & $90 \%$ & $0.09 \mathrm{ml} / \mathrm{L}$ \\
\hline Anticassure BG/BD & Anti-crease & Acryamide aqueous solution & Fiber preparation & $0.5 \mathrm{ml} / \mathrm{L}$ & $90 \%$ & $0.06 \mathrm{ml} / \mathrm{L}$ \\
\hline Sodium hydroxyl $50 \%(\mathrm{w} / \mathrm{v})$ & Alkaline system & Base & Fiber preparation & $4 \mathrm{ml} / \mathrm{L}$ & $100 \%$ & $0.57 \mathrm{ml} / \mathrm{L}$ \\
\hline Hydrogen peroxide 200 vol. & Oxidizing the dye & Oxidant reagent & Fiber preparation & $1.5 \mathrm{ml} / \mathrm{L}$ & $85 \%$ & $0.18 \mathrm{ml} / \mathrm{L}$ \\
\hline Acetic acid & Acid generator & Acid & Fiber preparation & $0.8 \mathrm{ml} / \mathrm{L}$ & $100 \%$ & $0.11 \mathrm{ml} / \mathrm{L}$ \\
\hline Zerox & $\begin{array}{l}\text { Hydrogen peroxide } \\
\text { neutralizer }\end{array}$ & Catalase & Fiber preparation & $0.6 \mathrm{ml} / \mathrm{L}$ & $90 \%$ & $0.08 \mathrm{ml} / \mathrm{L}$ \\
\hline Enzyme BG/FB & Bleaching & Fungal cellulase & Fiber preparation & $0.4 \mathrm{ml} / \mathrm{L}$ & $90 \%$ & $0.05 \mathrm{ml} / \mathrm{L}$ \\
\hline Sequion M150 & Water corrector & Composed by phosphanates/carboxylates & Dyeing & $1 \mathrm{ml} / \mathrm{L}$ & $100 \%$ & $0.14 \mathrm{ml} / \mathrm{L}$ \\
\hline Sodium chloride & Electrolyte & Electrolyte & Dyeing & $9 \mathrm{~g} / \mathrm{L}$ & $90 \%$ & $1.16 \mathrm{~g} / \mathrm{L}$ \\
\hline Sodium carbonate & Alkaline system & Base & Dyeing & $20 \mathrm{~g} / \mathrm{L}$ & $90 \%$ & $2.6 \mathrm{~g} / \mathrm{L}$ \\
\hline Procion Yellow H-EXL gran & Dyeing & Azo dye & Dyeing & $\begin{array}{c}0.45 \% \\
\text { (w dye/w fiber) }\end{array}$ & $10 \%$ & $0.006 \mathrm{~g} / \mathrm{L}$ \\
\hline Procion Deep Red H-EXL gran & Dyeing & Azo dye & Dyeing & $\begin{array}{c}2.8 \% \\
\text { (w dye/w fibre) }\end{array}$ & $10 \%$ & $0.04 \mathrm{~g} / \mathrm{L}$ \\
\hline Sandozin NRW LIQ ALT C & Detergent & Polyethylene glycol isotridecyl ether & Washing & $0.9 \mathrm{ml} / \mathrm{L}$ & $90 \%$ & $0.12 \mathrm{ml} / \mathrm{L}$ \\
\hline
\end{tabular}


Table 2 - Characteristics of the synthetic dyeing raw wastewaters and after SBR treatment and respective removal efficiencies.

\begin{tabular}{|c|c|c|c|c|c|c|c|c|}
\hline \multirow[b]{2}{*}{ Parameter } & \multirow{2}{*}{$\begin{array}{c}\text { Acrylic } \\
\text { Raw } \\
\text { Wastewater } \\
\end{array}$} & \multicolumn{3}{|c|}{ Polyester } & \multicolumn{3}{|c|}{ Cotton } & \multirow{2}{*}{$\begin{array}{c}\text { Maximum } \\
\text { Allowable } \\
\text { Value* }\end{array}$} \\
\hline & & $\begin{array}{c}\text { Raw } \\
\text { Wastewater } \\
\end{array}$ & After SBR & $\begin{array}{c}\text { Removal } \\
(\%)\end{array}$ & $\begin{array}{c}\text { Raw } \\
\text { Wastewater }\end{array}$ & After SBR & $\begin{array}{c}\text { Removal } \\
(\%)\end{array}$ & \\
\hline $\mathrm{pH}$ & 6.8 & 8.3 & & --- & 11.4 & & --- & $5.5-9.0$ \\
\hline Conductivity at $20^{\circ} \mathrm{C}(\mathrm{mS} / \mathrm{cm})$ & 1503.0 & 2.9 & n.d. & --- & 23.2 & n.d. & --- & \\
\hline Total suspended solids (mg/L) & 16.0 & 21.7 & 25.1 & & 67.0 & 28.3 & & \\
\hline Total nitrogen (mg N/L) & 16.4 & 15.9 & 13.3 & 16 & 3.9 & 3.1 & 21 & \\
\hline Nitrates $\left(\mathrm{mg} \mathrm{NO}_{3}{ }^{-} / \mathrm{L}\right)$ & 15.7 & 7.5 & n.d. & --- & 4.25 & n.d. & --- & \\
\hline Total phosphorus (mg P/L) & 0.2 & 3.0 & 2.4 & 20 & 5.9 & 5.7 & 3 & \\
\hline Dissolved phosphorus (mg P/L) & $<0.06$ & 2.7 & n.d. & --- & 0.1 & n.d. & --- & \\
\hline $\mathrm{COD}-$ Chemical oxygen demand $\left(\mathrm{mg} \mathrm{O}_{2} / \mathrm{L}\right)$ & 828.1 & 517.9 & 392.4 & 24 & 350.0 & 280.4 & 20 & 250 \\
\hline $\mathrm{BOD}_{5}-$ Biochemical oxygen demand $\left(\mathrm{mg} \mathrm{O}_{2} / \mathrm{L}\right)$ & $<1.0$ & 130.7 & 79.1 & 39 & 77.5 & 62.3 & 20 & 100 \\
\hline DOC - Dissolved organic carbon $(\mathrm{mg} \mathrm{C} / \mathrm{L})$ & 334.1 & 143.1 & 86.3 & 40 & 117.5 & 94.1 & 20 & \\
\hline Sulfates $(\mathrm{mg} / \mathrm{L})$ & 598.0 & 885.8 & n.d. & --- & 41.0 & n.d. & --- & \\
\hline Chlorides (mg Cl$-/ \mathrm{L})$ & 44.1 & 17.3 & n.d. & --- & 7981.8 & n.d. & --- & \\
\hline Alkalinity $\left(\mathrm{mg} \mathrm{CaCO}_{3} / \mathrm{L}\right)$ & 51.8 & 774.4 & n.d. & --- & 4425.0 & n.d. & --- & \\
\hline SOUR - Specific oxygen uptake rate $\left(\mathrm{mg} \mathrm{O}_{2} /\left(\mathrm{g}_{\mathrm{vss}} . \mathrm{h}\right)\right)$ & $<0.2$ & 27.0 & n.d. & --- & 5.6 & n.d. & --- & \\
\hline $\mathrm{BOD}_{5}: \mathrm{COD}$ ratio & $<0.0012$ & 0.26 & 0.20 & --- & 0.22 & 0.22 & --- & \\
\hline Maximum absorbance wavelength, $\lambda_{\max }(\mathrm{nm})$ & 610 & --- & n.d. & --- & 520 & n.d. & & \\
\hline Absorbance at $\lambda_{\max }$ (a.u.) & 1.592 & --- & n.d. & --- & 0.437 & 0.179 & $51 * *$ & \\
\hline Visible color after dilution $1: 40$ & visible & not visible & not visible & --- & visible & visible & --- & not visible \\
\hline Vibrio fischeri Inhibition 5 min (\%) & 94.0 & 74.5 & n.d. & --- & 0.0 & n.d. & --- & \\
\hline Vibrio fischeri Inhibition $15 \mathrm{~min}(\%)$ & 96.0 & 82.5 & n.d. & --- & 0.0 & n.d. & --- & \\
\hline Vibrio fischeri Inhibition $30 \mathrm{~min}(\%)$ & 97.0 & 84.5 & n.d. & --- & 0.0 & n.d. & --- & \\
\hline
\end{tabular}

n.d. - not determined

* Portuguese legislation for discharge of textile wastewaters (Ordinance No. 423 of June 25, 1997).

** calculated from the absorbance of raw wastewater at $\mathrm{pH} 7.0$ (0.3617 abs. units) 
Table 3 - Characteristics of the synthetic acrylic dyeing wastewaters after Fenton reaction and SBR and respective removal efficiencies (within brackets) and global removals. Runs\#1 to \#3 represent experiments with decreasing doses of chemicals in the Fenton's stage.

\begin{tabular}{|c|c|c|c|c|c|c|c|c|c|c|}
\hline \multirow[b]{2}{*}{ Parameter } & \multicolumn{3}{|c|}{ Run \#1 - Optimal dose of chemicals } & \multicolumn{3}{|c|}{ Run \#2 - 0.75 of optimal dose of chemicals } & \multicolumn{3}{|c|}{ Run \#3 - 0.5 of optimal dose of chemicals } & \multirow[b]{2}{*}{$\begin{array}{c}\text { Maximum } \\
\text { Allowable } \\
\text { Value* }\end{array}$} \\
\hline & $\begin{array}{c}\text { Fenton } \\
\text { (removal } \\
(\%))\end{array}$ & $\begin{array}{c}\text { SBR } \\
\text { (removal } \\
(\%))\end{array}$ & $\begin{array}{c}\text { Global } \\
\text { Removal } \\
(\%)\end{array}$ & $\begin{array}{c}\text { Fenton } \\
\text { (removal } \\
(\%))\end{array}$ & $\begin{array}{c}\text { SBR } \\
\text { (removal } \\
(\%))\end{array}$ & $\begin{array}{c}\text { Global } \\
\text { Removal } \\
(\%)\end{array}$ & $\begin{array}{c}\text { Fenton } \\
\text { (removal } \\
(\%))\end{array}$ & $\begin{array}{c}\text { SBR } \\
\text { (removal } \\
(\%))\end{array}$ & $\begin{array}{c}\text { Global } \\
\text { Removal } \\
(\%)\end{array}$ & \\
\hline $\mathrm{pH}$ & 7.10 & 7.15 & --- & 7.06 & 7.09 & --- & 7.01 & 6.98 & --- & $5.5-9.0$ \\
\hline Total nitrogen (mg N/L) & $16.0(2)$ & $8.8(45)$ & 46 & $16.1(2)$ & $9.3(42)$ & 43 & $16.3(2)$ & $12.4(23)$ & 24 & \\
\hline Total phosphorus (mg P/L) & $0.2(0)$ & $0.61\left(47^{* *}\right)$ & 48 & $0.2(0)$ & $0.20\left(75^{* *}\right)$ & 75 & $0.2(0)$ & $0.16(68 * *)$ & 68 & \\
\hline $\mathrm{COD}\left(\mathrm{mg} \mathrm{O}_{2} / \mathrm{L}\right)$ & $289.0(65)$ & $14.6(95)$ & 98 & $294.5(64)$ & $104.3(65)$ & 87 & $349.7(58)$ & $273.7(22)$ & 67 & 250 \\
\hline $\mathrm{BOD}_{5}\left(\mathrm{mg} \mathrm{O}_{2} / \mathrm{L}\right)$ & 116.5 & $6.4(95)$ & 95 & 78.8 & $12.0(85)$ & 85 & 46.8 & $14.5(69)$ & 69 & 100 \\
\hline DOC (mg C/L) & $112.0(66)$ & $5.4(95)$ & 98 & $124.7(63)$ & $34.5(72)$ & 90 & $132.3(60)$ & $109.3(17)$ & 67 & \\
\hline $\begin{array}{l}\text { SOUR - Specific oxygen uptake rate } \\
\left(\mathrm{mg} \mathrm{O}_{2} /(\text { gvss .h })\right)\end{array}$ & 17.9 & n.d. & --- & 10.2 & n.d. & --- & 2.7 & n.d. & --- & \\
\hline $\mathrm{BOD}_{5}: \mathrm{COD}$ ratio & 0.40 & 0.46 & --- & 0.27 & 0.12 & --- & 0.13 & 0.05 & --- & \\
\hline Absorbance at $\lambda_{\max }$ (a.u.) & $\begin{array}{l}0.0079 \\
(99 * * *)\end{array}$ & $\begin{array}{c}0.0025 \\
(68 * * * *)\end{array}$ & $\geq 99$ & $\begin{array}{l}0.0080 \\
(99 * * *)\end{array}$ & $\begin{array}{c}0.0025 \\
(69 * * * *)\end{array}$ & $\geq 99$ & $\begin{array}{l}0.0089 \\
(99 * * *)\end{array}$ & $\begin{array}{c}0.0025 \\
(72 * * * *)\end{array}$ & $\geq 99$ & \\
\hline Visible color after dilution 1:40 & not visible & not visible & --- & not visible & not visible & --- & not visible & not visible & --- & not visible \\
\hline Vibrio fischeri Inhibition $5 \mathrm{~min}(\%)$ & 29 & n.d. & --- & 38 & n.d. & --- & 77 & n.d. & --- & \\
\hline Vibrio fischeri Inhibition $15 \min (\%)$ & 27 & n.d. & --- & 41 & n.d. & --- & 81 & n.d. & --- & \\
\hline Vibrio fischeri Inhibition $30 \mathrm{~min}(\%)$ & 29 & n.d. & --- & 41 & n.d. & --- & 82 & n.d. & --- & \\
\hline
\end{tabular}

n.d. - not determined

* Portuguese legislation for discharge of textile wastewaters (Ordinance No. 423 of June 25, 1997).

** calculated from total phosphorus in effluent after Fenton reaction after adding phosphate buffer $(1.17,0.79,0.5 \mathrm{mg}$ P/L in run \#1, \#2, \#3, respectively)

*** calculated from the absorbance at $610 \mathrm{~nm}$ of raw wastewater at $\mathrm{pH} 3.5$ (1.624 abs. units)

$* * * *$ calculated from the absorbance at $610 \mathrm{~nm}$ of wastewater after Fenton at pH $7.0(0.0079,0.0080$ and 0.0089 abs. units in run \#1, \#2 and \#3, respectively) 
Table 4 - Characteristics of the synthetic cotton dyeing wastewater after Fenton reaction and SBR and respective removal efficiencies (within brackets) and global removals. Runs\#1 to \#3 represent experiments with decreasing doses of chemicals in the Fenton's stage.

\begin{tabular}{|c|c|c|c|c|c|c|c|c|c|c|}
\hline \multirow[b]{2}{*}{ Parameter } & \multicolumn{3}{|c|}{ Run \#1- Optimal dose of chemicals } & \multicolumn{3}{|c|}{ Run \#2 - 0.5 of optimal dose of chemicals } & \multicolumn{3}{|c|}{ Run \#3 - 0.25 of optimal dose of chemicals } & \multirow[b]{2}{*}{$\begin{array}{c}\text { Maximum } \\
\text { Allowable } \\
\text { Value* }\end{array}$} \\
\hline & $\begin{array}{c}\text { Fenton } \\
\text { (removal } \\
(\%))\end{array}$ & $\begin{array}{c}\text { SBR } \\
\text { (removal } \\
(\%))\end{array}$ & $\begin{array}{c}\text { Global } \\
\text { Removal } \\
(\%)\end{array}$ & $\begin{array}{c}\text { Fenton } \\
\text { (removal } \\
(\%))\end{array}$ & $\begin{array}{c}\text { SBR } \\
\text { (removal } \\
(\%))\end{array}$ & $\begin{array}{c}\text { Global } \\
\text { Removal } \\
(\%)\end{array}$ & $\begin{array}{c}\text { Fenton } \\
\text { (removal } \\
(\%))\end{array}$ & $\begin{array}{c}\text { SBR } \\
\text { (removal } \\
(\%))\end{array}$ & $\begin{array}{c}\text { Global } \\
\text { Removal } \\
(\%)\end{array}$ & \\
\hline$\overline{\mathrm{pH}}$ & 6.99 & 7.05 & $\overline{---}$ & 7.04 & 7.10 & $\overline{---}$ & 7.09 & 7.03 & $\overline{---}$ & $5.5-9.0$ \\
\hline Total nitrogen (mg N/L) & $3.9(0)$ & $1.2(82)$ & 82 & $3.9(0)$ & $2.1(63)$ & 63 & $3.8(3)$ & $3.7(16)$ & 18 & \\
\hline Total phosphorus (mg P/L) & $5.9(0)$ & $4.8(19)$ & 19 & $5.9(0)$ & $5.2(12)$ & 12 & $5.8(2)$ & $5.6(3)$ & 5 & \\
\hline $\mathrm{COD}\left(\mathrm{mg} \mathrm{O}_{2} / \mathrm{L}\right)$ & $262.1(25)$ & $43.2(84)$ & 88 & $281.9(20)$ & $113.2(60)$ & 68 & $318.6(9)$ & $261.8(18)$ & 25 & 250 \\
\hline $\mathrm{BOD}_{5}(\mathrm{mg} \mathrm{O} / \mathrm{L})$ & $135.7(0)$ & $22.8(83)$ & 83 & $112.9(0)$ & $45.1(60)$ & 60 & $88.0(0)$ & $72.3(18)$ & 18 & 100 \\
\hline DOC (mg C/L) & $60.2(49)$ & $9.95(84)$ & 92 & $94.1(20)$ & $37.6(60)$ & 68 & $100.3(15)$ & $82.0(18)$ & 30 & \\
\hline $\begin{array}{l}\text { SOUR - Specific oxygen uptake rate } \\
\left(\mathrm{mg} \mathrm{O}_{2} /(\text { gvss .h })\right)\end{array}$ & 15.51 & n.d. & --- & 8.11 & n.d. & --- & 2.54 & n.d. & --- & \\
\hline $\mathrm{BOD}_{5}: \mathrm{COD}$ ratio & 0.52 & 0.53 & --- & 0.40 & 0.40 & --- & 0.33 & 0.28 & --- & \\
\hline Absorbance at $\lambda_{\max }$ (a.u.) & $\begin{array}{l}0.0331 \\
(90 * * *)\end{array}$ & $\begin{array}{c}0.0037 \\
(87 * * * *)\end{array}$ & 99 & $\begin{array}{l}0.0310 \\
(91 * * *)\end{array}$ & $\begin{array}{c}0.0053 \\
(82 * * * *)\end{array}$ & 98 & $\begin{array}{l}0.0349 \\
(89 * * *)\end{array}$ & $\begin{array}{c}0.0126 \\
(67 * * * *)\end{array}$ & 96 & \\
\hline Visible color after dilution 1:40 & not visible & not visible & --- & not visible & not visible & --- & not visible & not visible & --- & not visible \\
\hline Vibrio fischeri Inhibition $5 \min (\%)$ & 0.0 & n.d. & --- & 0.0 & n.d. & --- & 0.0 & n.d. & --- & \\
\hline Vibrio fischeri Inhibition $15 \mathrm{~min}(\%)$ & 0.0 & n.d. & --- & 0.0 & n.d. & --- & 0.0 & n.d. & --- & \\
\hline Vibrio fischeri Inhibition $30 \mathrm{~min}(\%)$ & 0.0 & n.d. & --- & 0.0 & n.d. & --- & 0.0 & n.d. & --- & \\
\hline
\end{tabular}

n.d. - not determined

* Portuguese legislation for discharge of textile wastewaters (Ordinance No. 423 of June 25, 1997).

** calculated from total phosphorus in effluent after Fenton reaction after adding urea ( 6.8, 5.6, 4.4 mg N/L in run \#1, \#2, \#3, respectively)

*** calculated from the absorbance at $520 \mathrm{~nm}$ of raw wastewater at $\mathrm{pH} 3.5$ (0.3615 abs. units)

$* * * *$ calculated from the absorbance at $520 \mathrm{~nm}$ of wastewater after Fenton at pH 7.0 ( $0.0276,0.0293$ and 0.0368 abs. units in run \#1, \#2 and \#3, respectively) 
Table 5 - Characteristics of the synthetic polyester dyeing wastewaters after Fenton reaction and SBR and respective removal efficiencies (within brackets), and global removals. Runs\#1 to \#3 represent experiments with decreasing doses of chemicals in the Fenton's stage.

\begin{tabular}{|c|c|c|c|c|c|c|c|c|c|c|}
\hline \multirow[b]{2}{*}{ Parameter } & \multicolumn{3}{|c|}{ Run \#1 - Optimal dose of chemicals } & \multicolumn{3}{|c|}{ Run \#2 - 0.5 of optimal dose of chemicals } & \multicolumn{3}{|c|}{ Run \#3- 0.25 of optimal dose of chemicals } & \multirow{2}{*}{$\begin{array}{c}\text { Maximum } \\
\text { Allowable } \\
\text { Value* }\end{array}$} \\
\hline & $\begin{array}{c}\text { Fenton } \\
\text { (removal } \\
(\%))\end{array}$ & $\begin{array}{c}\text { SBR } \\
\text { (removal } \\
(\%))\end{array}$ & $\begin{array}{c}\text { Global } \\
\text { Removal } \\
(\%)\end{array}$ & $\begin{array}{c}\text { Fenton } \\
\text { (removal } \\
(\%))\end{array}$ & $\begin{array}{c}\text { SBR } \\
\text { (removal } \\
(\%))\end{array}$ & $\begin{array}{c}\text { Global } \\
\text { Removal } \\
(\%)\end{array}$ & $\begin{array}{c}\text { Fenton } \\
\text { (removal } \\
(\%))\end{array}$ & $\begin{array}{c}\text { SBR } \\
\text { (removal } \\
(\%))\end{array}$ & $\begin{array}{c}\text { Global } \\
\text { Removal } \\
(\%)\end{array}$ & \\
\hline$\overline{\mathrm{pH}}$ & 7.05 & 7.10 & $\overline{---}$ & 7.11 & 7.08 & $\overline{---}$ & 7.15 & 7.10 & $\overline{---}$ & $5.5-9.0$ \\
\hline Total nitrogen (mg N/L) & $15.1(5)$ & $12.3(19)$ & 23 & $15.3(4)$ & $12.4(19)$ & 22 & $15.9(0)$ & $13.3(16)$ & 16 & \\
\hline Total phosphorus (mg P/L) & $2.8(7)$ & $2.2(20)$ & 25 & $2.9(3)$ & $2.2(23)$ & 25 & $3.0(0)$ & $2.4(20)$ & 20 & \\
\hline $\mathrm{COD}\left(\mathrm{mg} \mathrm{O}_{2} / \mathrm{L}\right)$ & $221.1(57)$ & $44.4(80)$ & 91 & $291.7(44)$ & $104.3(64)$ & 80 & $389.7(25)$ & $267.7(31)$ & 48 & 250 \\
\hline $\mathrm{BOD}_{5}\left(\mathrm{mg} \mathrm{O}_{2} / \mathrm{L}\right)$ & $62.8(52)$ & $11.4(82)$ & 91 & $80.2(39)$ & $29.4(63)$ & 78 & $103.8(21)$ & $54.3(48)$ & 58 & 100 \\
\hline DOC $(\mathrm{mg} \mathrm{C} / \mathrm{L})$ & $63.4(56)$ & $12.6(80)$ & 91 & $80.6(44)$ & $27.7(66)$ & 81 & $106.9(25)$ & $58.1(46)$ & 59 & \\
\hline $\begin{array}{l}\text { SOUR - Specific oxygen uptake rate } \\
\left(\mathrm{mg} \mathrm{O}_{2} /\left(g_{V s s} . h\right)\right)\end{array}$ & 30.0 & n.d. & --- & 29.0 & n.d. & --- & 28 & n.d. & --- & \\
\hline $\mathrm{BOD}_{5}: \mathrm{COD}$ ratio & 0.28 & 0.26 & --- & 0.28 & 0.28 & --- & 0.27 & 0.20 & --- & \\
\hline Visible color after dilution 1:40 & not visible & not visible & --- & not visible & not visible & --- & not visible & not visible & --- & not visible \\
\hline Vibrio fischeri Inhibition $5 \min (\%)$ & 0.0 & n.d. & --- & 10.4 & n.d. & --- & 43.3 & n.d. & --- & \\
\hline Vibrio fischeri Inhibition $15 \min (\%)$ & 0.0 & n.d. & --- & 15.0 & n.d. & --- & 55.8 & n.d. & --- & \\
\hline Vibrio fischeri Inhibition $30 \mathrm{~min}(\%)$ & 0.0 & n.d. & --- & 17.6 & n.d. & --- & 59.4 & n.d. & --- & \\
\hline
\end{tabular}

n.d. - not determined

* Portuguese legislation for discharge of textile wastewaters (Ordinance No. 423 of June 25, 1997). 


\section{Figures captions}

Figure 1 - Diagram of the SBR set-up.

Figure 2 - Variation of COD (a), $\mathrm{BOD}_{5}(\mathrm{~b}), \mathrm{DOC}(\mathrm{c})$, total nitrogen (d) and color removals during 10 cycles of SBR operation for polyester and cotton wastewaters (concentrations in the raw effluents are given in Table 2).

Figure 3 - Variation of $\mathrm{COD}, \mathrm{BOD}_{5}$, DOC, total nitrogen and color removals during 10 cycles of SBR operation for acrylic effluent, previously treated by Fenton's oxidation. Runs\#1 to \#3 represent experiments with decreasing doses of chemicals in the Fenton's stage (concentrations in the starting effluent are given in Table 3).

Figure 4 - Variation of $\mathrm{COD}, \mathrm{BOD}_{5}, \mathrm{DOC}$, total nitrogen and color removals during 10 cycles of SBR operation for synthetic cotton dyeing effluent, previously treated by Fenton's reaction. Runs\#1 to \#3 represent experiments with decreasing doses of chemicals in the Fenton's stage (concentrations in the starting effluent are given in Table 4).

Figure 5 - Evolution of $\mathrm{COD}, \mathrm{BOD}_{5}, \mathrm{DOC}$ and total nitrogen removals during 10 cycles of SBR operation for polyester dyeing wastewater, previously treated by Fenton's reaction. Runs\#1 to \#3 represent experiments with decreasing doses of chemicals in the Fenton's stage (concentrations in the starting effluent are given in Table 5).

Figure 6 - Total operating costs for biological, Fenton alone and integrated treatment of acrylic, cotton and polyester dyeing wastewaters. 
Figure 1

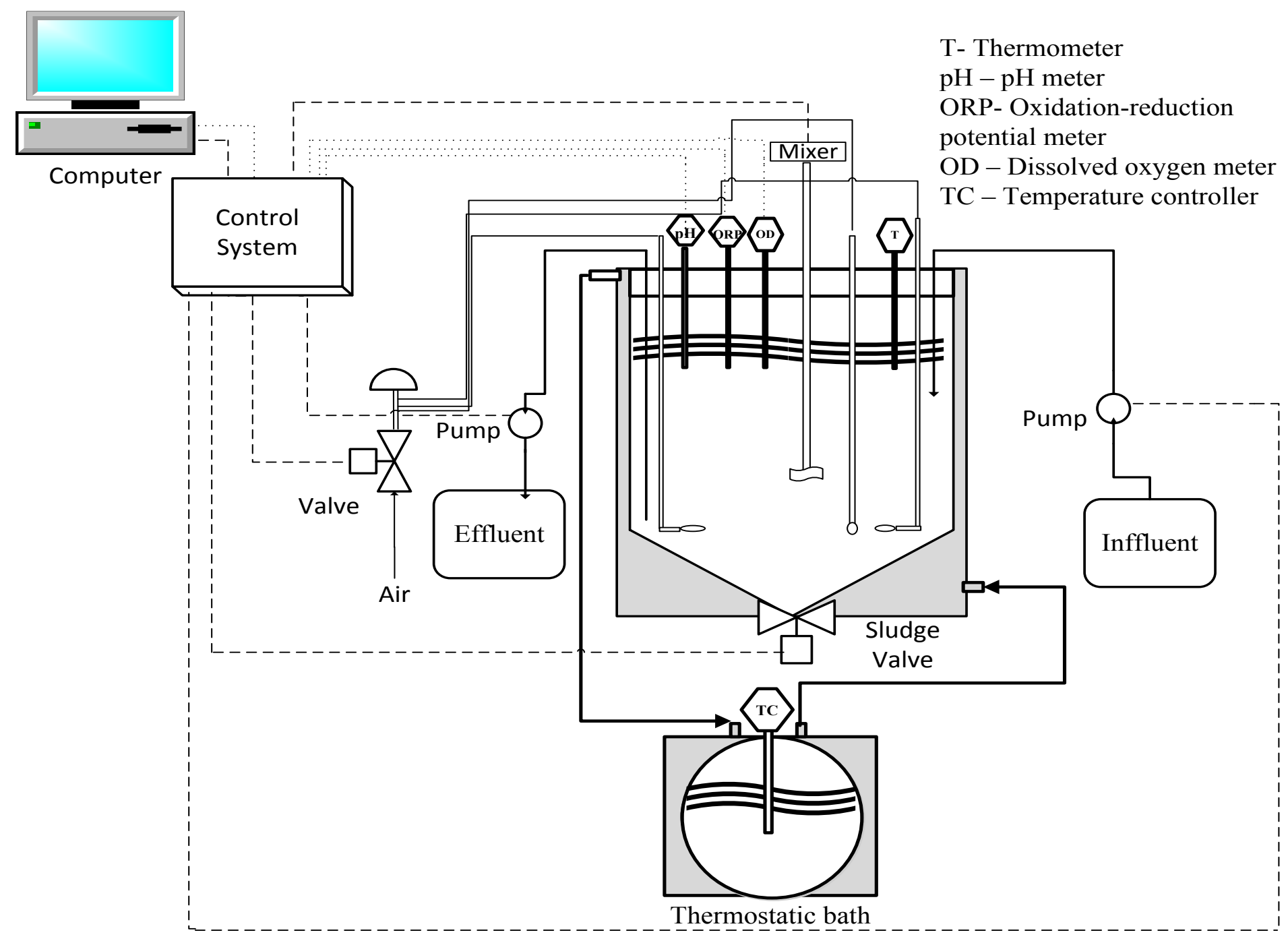


Figure 2
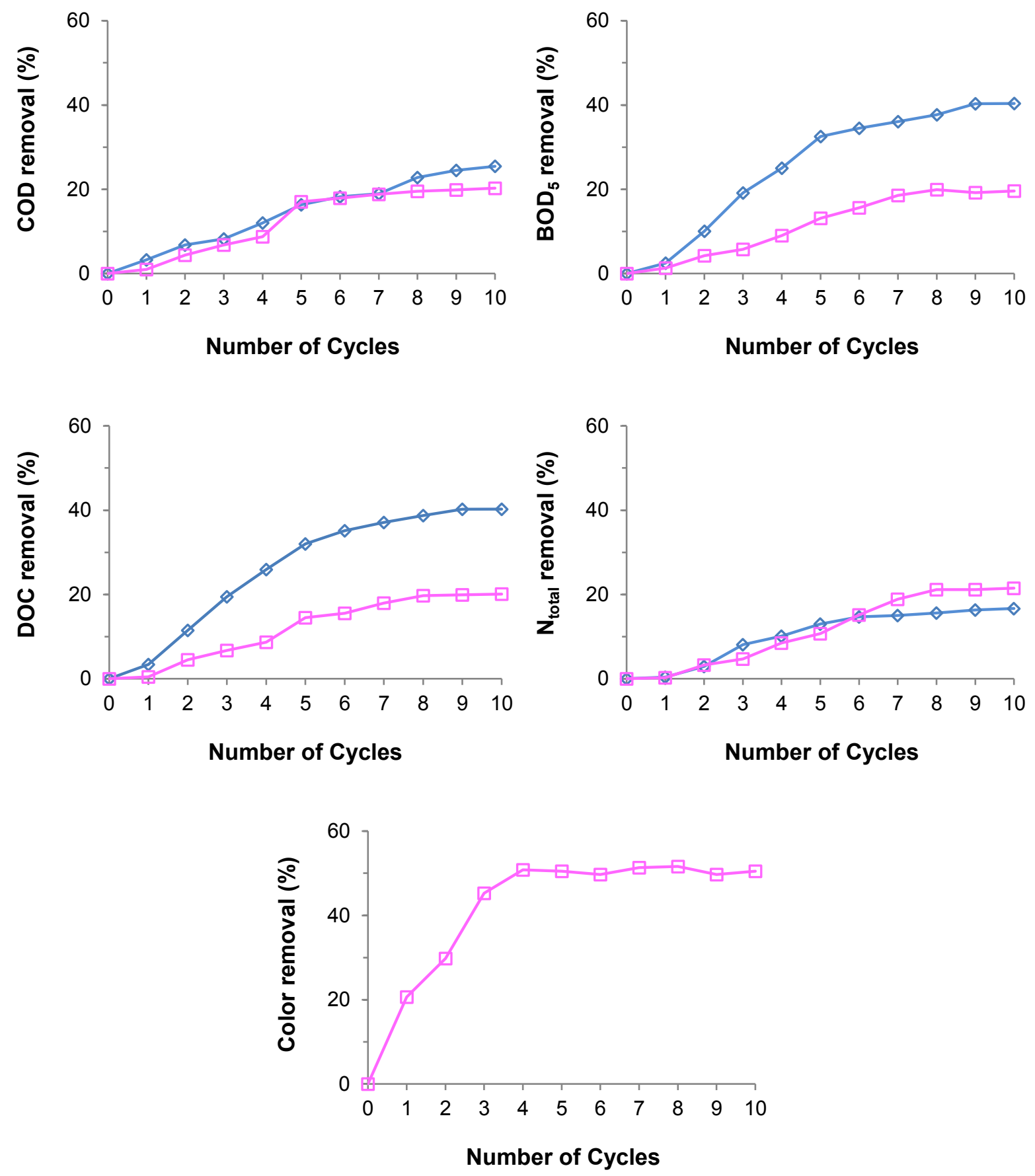

$\vartheta$ Polyester $\square$ Cotton 
Figure 3
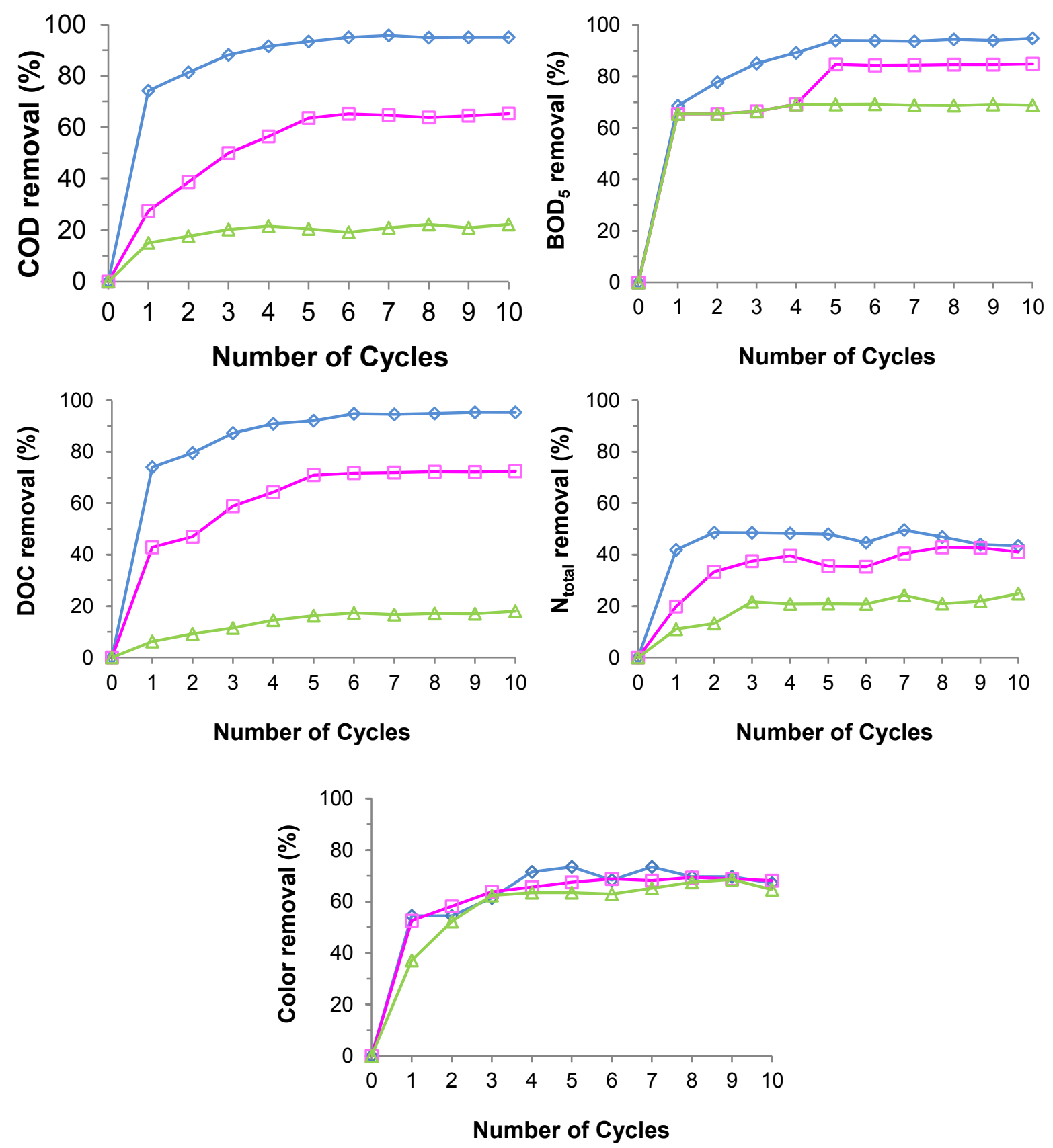

$\triangleleft$ Run \#1 - optimal doses of chemicals $\quad \square \quad$ Run \#2 - 0.75 of optimal doses of chemicals $\quad \triangle \quad$ Run \#3 - 0.5 of optimal doses of chemicals 
Figure 4
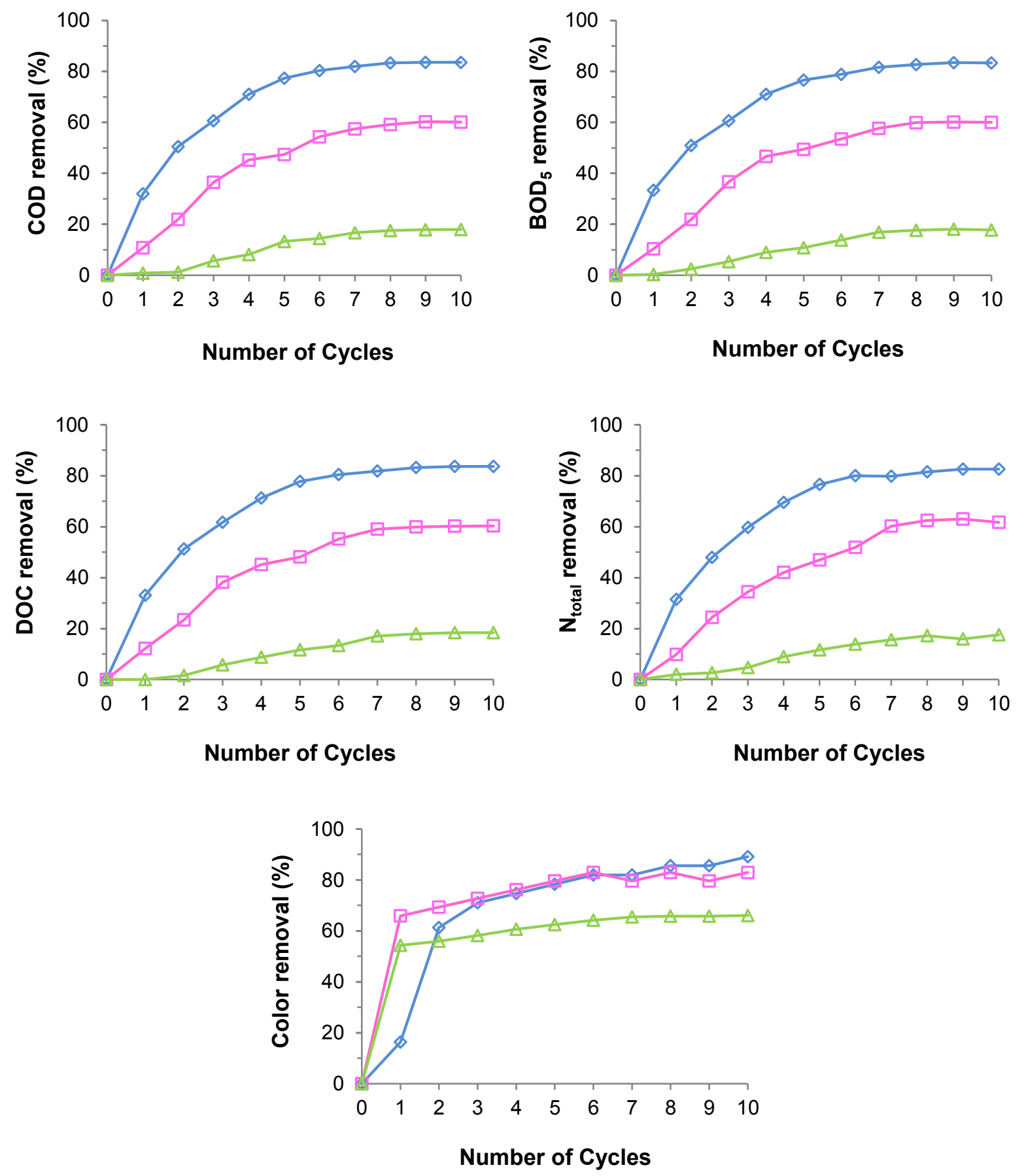

$\dashv$ Run \#1 - optimal doses of chemicals $\quad \square \quad$ Run \#2 -0.5 of optimal doses of chemicals $\quad \triangle$ Run \#3 -0.25 of optimal doses of chemicals 


\section{Figure 5}

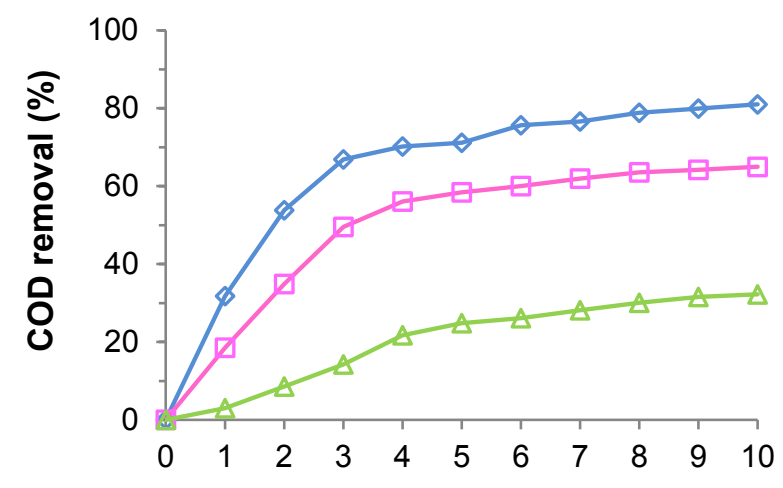

Number of Cycles

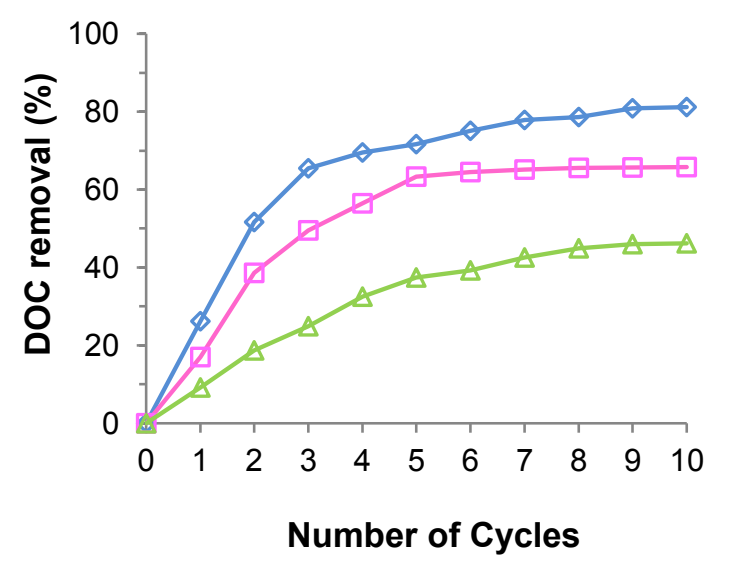

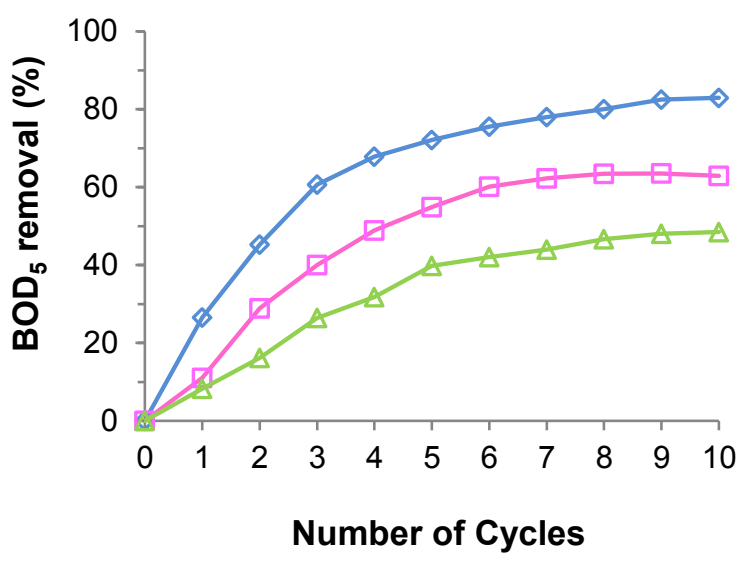

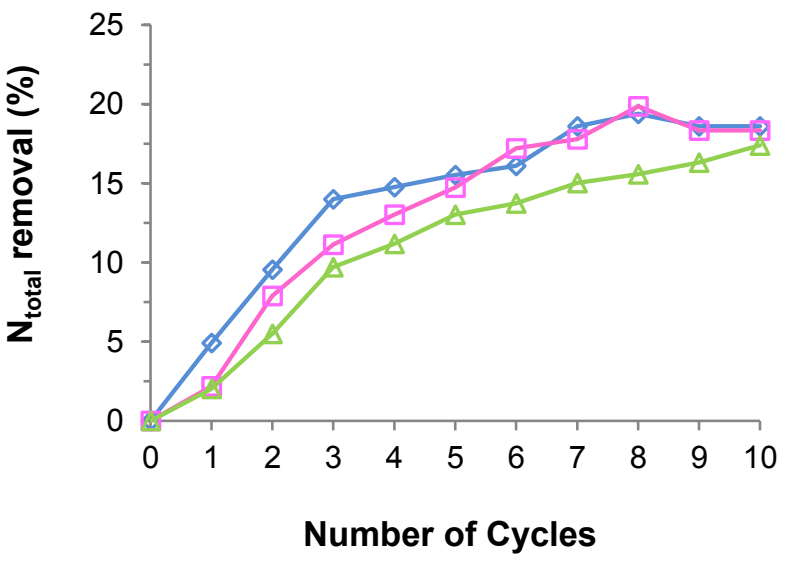

$\neg$ Run \#1 - optimal doses of chemicals $\quad \square \quad$ Run \#2 - 0.5 of optimal doses of chemicals $\quad \triangle$ Run \#3 -0.25 of optimal doses of chemicals 
Figure 6

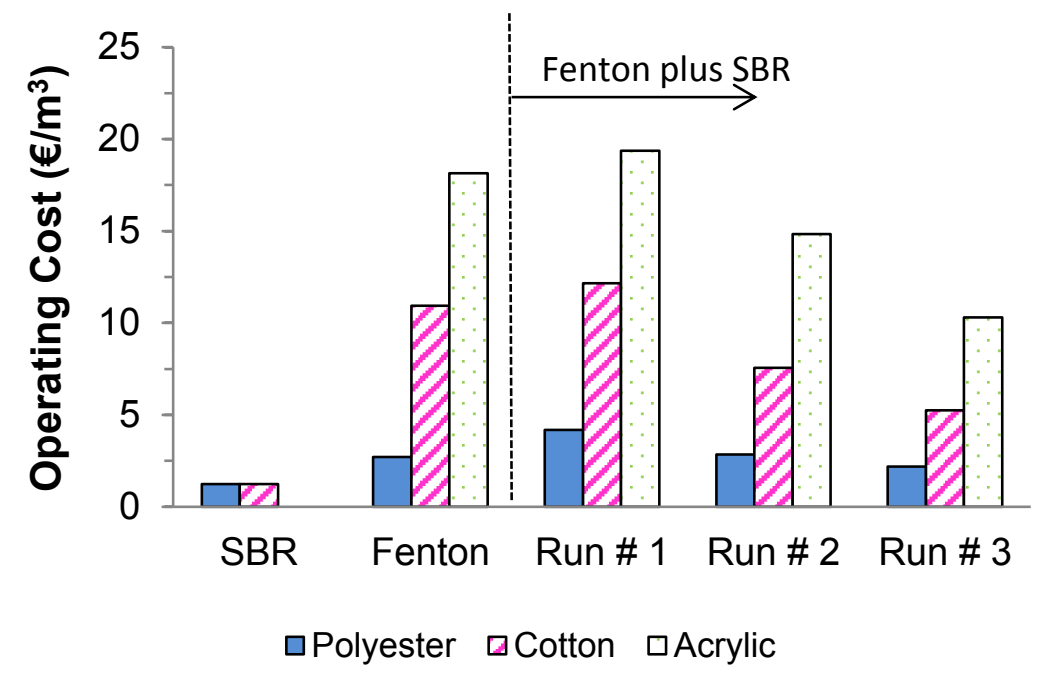

